\title{
A Tribute to Charles Hogg Douglas, 1923-2004
}

\author{
Edward L. Bousfield and Francis R. COOK
}

Canadian Museum of Nature, Postal Station D, Ottawa, Ontario K1P 6P4 Canada

Bousfield, Edward L., and Francis R. Cook. 2012. A tribute to Charles Hogg Douglas, 1923-2004. Canadian Field-Naturalist 126(2): 164-166.

Tributes to former staff of Canadian museums and their encouragement of the inventorying and study of the natural history of Canada tend to emphasize the contributions and personalities of directors, research scientists, and curators. Often inadequately recognized are the support staff, artists, and technicians who aided the research and publications produced. The death of Charles Douglas on 22 April 2004 at age 80 marked the passing of the last person to hold the position of permanent staff artist in zoology at the Canadian Museum of Nature (previously the Natural History Museum of the National Museum of Canada and subsequently the National Museum of Natural Sciences, National Museums of Canada) in Ottawa. Charles followed in the footsteps of staff artists Claude Johnson, John Crosby, and John Tottenham, and a number of contractors, including Alan Brooks and F. C. Hennessy early in the 20th century. Susan Laurie-Bourque and Aleta Karstad Schueler late in the 20th century subsequently fulfilled museum zoology artistic needs on contract.

Charles Hogg Douglas was born near Aberdeen, on the east coast of Scotland, 28 December 1923, and moved to Canada when he was five. (His middle name was a carryon from an ancestral maternal family surname.) His father was a golf professional at Trenton (1928 to 1932) and Cornwall (1932 to 1945), and Charles attended Cornwall Collegiate and Vocational School. He became an apprentice draftsman with Courtauld Canada Ltd. after quitting school in grade 10. At 19 he enlisted in the Royal Canadian Air Force. Mishaps with a Tiger Moth biplane redirected him from pilot training. He was discharged in 1945 with the rank of Sergeant Bombardier. On his return to civilian life, he tried a variety of jobs in finance, car sales, and real estate. But simultaneously he did as much freelance commercial art as possible, including humorous but tasteful cartoons published in Oui and Playboy and elsewhere.

In 1966, his artistic precision won him a competition for the position of staff artist (zoological illustrator) with the Natural History Museum in Ottawa. He remained in this position with the Museum for the remainder of his career, retiring in 1986 as Artist in the Zoology Division. During his 20-year career with the Museum, he illustrated numerous technical journal papers by staff research scientists and major Museum publications on the Canadian fauna: A Guide to the
Freshwater Sport Fishes of Canada (by D. E. McAllister and E. J. Crossman, National Museum of Natural Sciences, National Museums of Canada, Ottawa, 1973) and An Introduction to the Amphibians and Reptiles of Canada (F. R. Cook, National Museum of Natural Sciences, National Museums of Canada, Ottawa, 1984) as well as contributions to The Mammals of Canada (A. W. F. Banfield, University of Toronto Press for the National Museum of Natural Sciences, National Museums of Canada, Toronto, 1974) and The Freshwater Molluscs of Canada (A. H. Clarke, Jr., National Museum of Natural Sciences, National Museums of Canada, Ottawa, 1981). He also illustrated Munoo: The Life of an Arctic Sled Dog (C. F. Harington, Polar Bear Publishing, 1986).

Charles Douglas was arguably the most dynamic, and perhaps the most versatile, artist ever employed by the Museum. He got on well with the scientists who assigned and supervised his work, and his painstaking attention to creating a natural image of his subjects allowed him, despite the majority of his work being done in the museum from preserved material, to satisfy the most demanding supervision. His almost unique ability to take criticism with good humour and make revisions (but not always without mild exasperation, especially over the despised flatfishes, difficult due to their time-consuming, numerous small scales) was a strong asset. His most notable participation in a Museum field expedition was one down the estuary of the St. Lawrence River in 1969 with E. L. Bousfield. Some of the results of that expedition are being included in a current study on burrowing amphipods by E.L.B.

Besides success as an illustrator of research publications, Charles provided illustrations for the series of museum handouts that began with a seven-part series on reptiles and amphibians in 1979 to facilitate response to enquiries from students. The series, entitled Neotoma, is available on the Canadian Museum of Nature website at http://www.nature.ca/en/about-us/productsservices /shopping/publications/neotoma. The name Neotoma comes from Neotoma cinera, the Pack Rat, in honour of its habit of collecting objects (the museum's Neotoma represents a collection of facts). Later, Charles' conception of the Nature Notebook series was a major contribution to bringing natural history to the attention of the general public, particularly younger readers, in an effective way. This started as a weekly series which 


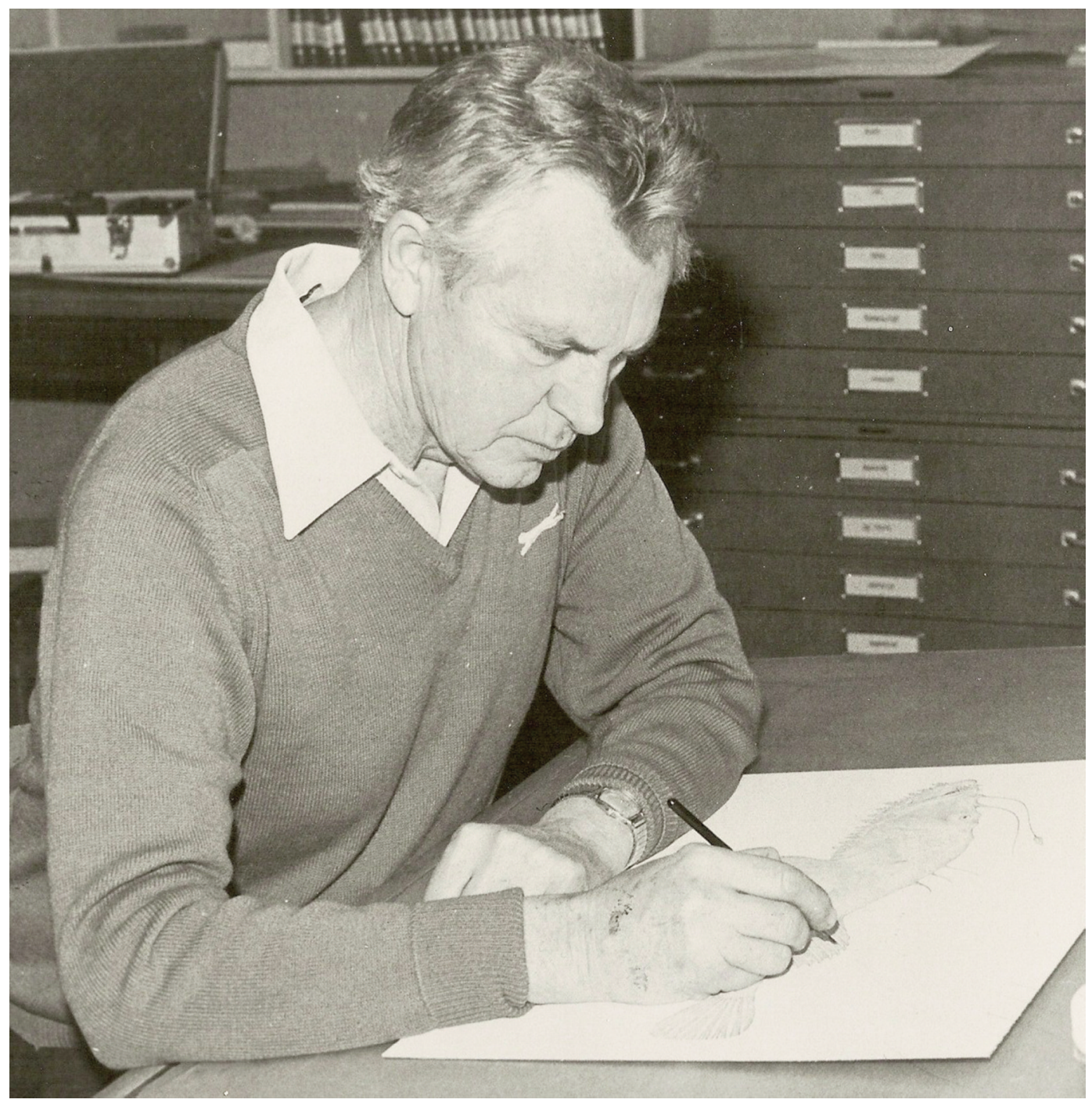

FIGURE 1. Charles H. Douglas at work creating an illustration from a museum specimen of an angler fish, possibly a Monkfish, Lophius americanus.

ran with great success in the Ottawa Citizen and a number of other newspapers across Canada in both English and French. The accounts covered both Canadian species and a selection worldwide. Initial ones were written by him, and he established the style and type of content for the series. Later, some researchers contributed additional accounts in their specialties. Subsequently, the series was published in book form in five volumes of 52 accounts each. Most recently, these have been posted on the Canadian Museum of Nature website (http://nature.ca/notebooks/english/mon2.htm), with updated text and some photographs added.

Even after he retired, Charles' unpublished illustrations on file at the museum continued to appear in major publications, notably in The Encyclopedia of Canadian Fishes (B. W. Coad with H. Waszczuk and I. Labignan, Canadian Museum of Nature and Canadian Sportfishing Productions, 1995). His drawings of 46 arctic and 15 additional non-arctic species will be included in the forthcoming multi-authored Marine Fish of Arctic Canada, sponsored by the Museum and Fisheries and Oceans Canada, started before Charles joined the Museum staff and only now nearing completion.

Charles Douglas was much more than a cartoonist, zoological illustrator, and popularizer of natural history. Two major recreational activities occupied much of his time when he was not at the museum or at his home drafting table. He was an avid fan of local horse 
racing and owned a set of harness racers that ran on regional racetracks. He was also a lifetime golfer of near-professional status who was dubbed as "sweet swinging" on courses from Aylmer (Gatineau), Quebec, to North Bay, Ontario, where he often led the field in tournaments.

Charles married Jeannine Morin of Timmins in 1951, and they had three children, Brian (born in 1952), James (born in 1953), and William (born in 1961).

\section{Acknowledgements}

Our thanks to his wife, Jeannine, and son Brian for materials and background as well as the photograph of Charles Douglas at work. Jeannine also corrected an earlier draft, as did Charles Gruchy and Brian Coad. The latter provided the count of his contribution to the arctic fish of Canada volume in preparation and read an earlier draft. Special thanks to Andy Marshall for material in his fine profile cited below.

\section{Literature Cited}

Cook, F. R. 1984. Charles Douglas. Page 200 in Introduction to Canadian Amphibians and Reptiles. National Museum of Natural Sciences, National Museums of Canada, Ottawa, Ontario.

Marshall, A. 2003. Charles Douglas: from fish to sex symbols, he's drawn them all. Wildlands Advocate Alberta [WLA] 11(6): 20. [Six of Charles' drawings-five mammals and one frog - are scattered throughout the issue].

Received 18 July 2012

Accepted 8 August 2012 